\title{
HIF Signaling Pathway in Pheochromocytoma and Other Neuroendocrine Tumors
}

\section{JOCHMANOVÁ ${ }^{1,2}$, T. ZELINKA ${ }^{3}$, J. WIDIMSKÝ Jr. ${ }^{3}$, K. PACAK ${ }^{2}$}

${ }^{1}$ First Department of Internal Medicine, Faculty of Medicine, P. J. Šafárik University, Košice, Slovakia, ${ }^{2}$ Program in Reproductive and Adult Endocrinology, Eunice Kennedy Shriver National Institute of Child Health and Human Development, NIH, Bethesda, MD, USA, ${ }^{3}$ Third Department of Medicine, Department of Endocrinology and Metabolism, First Faculty of Medicine, Charles University and General University Hospital, Prague, Czech Republic

Received March 20, 2014

Accepted March 26, 2014

\section{Summary}

Hypoxia-inducible factors (HIFs) are transcription factors controlling energy, iron metabolism, erythropoiesis, and development. Dysregulation of these proteins contributes to tumorigenesis and cancer progression. Recent findings revealed the important role of HIFs in the pathogenesis of neuroendocrine tumors, especially pheochromocytoma (PHEO) and paraganglioma (PGL). PHEOs and PGLs are catecholamineproducing tumors arising from sympathetic- or parasympatheticderived chromaffin tissue. To date, eighteen PHEO/PGL susceptibility genes have been identified. Based on the main signaling pathways, PHEOs/PGLs have been divided into two clusters, pseudohypoxic cluster 1 and cluster 2, rich in kinase receptor signaling and protein translation pathways. Recent data suggest that both clusters are interconnected via the HIF signaling and its role in tumorigenesis is supported by newly described somatic and germline mutations in HIF2A gene in patients with PHEOs/PGLs associated with polycythemia, and in some of them also with somatostatinoma. Moreover, HIFa signaling has also been shown to be upregulated in neuroendocrine tumors other than PHEO/PGL. Some of these tumors are components of hereditary tumor syndromes which can be associated with PHEO/PGL, but also in ileal carcinoids or melanoma. HIF signaling appears to be one of the crucial players in tumorigenesis, which could suggest new therapeutic approaches for treatment of neuroendocrine tumors.

\section{Key words}

Pheochromocytoma • Paraganglioma • Hypoxia-inducible factor • Oxygen sensing • Therapy

\section{Corresponding author}

K. Pacak, Section on Medical Neuroendocrinology, Program in Reproductive and Adult Endocrinology, Eunice Kennedy Shriver NICHD, NIH, Building 10-CRC, 1E-3140, 10 Center Dr., Bethesda, MD, 20892-1109, USA. E-mail: karel@mail.nih.gov

\section{Introduction}

PHEOs and PGLs are rare neuroendocrine catecholamine producing tumors. PHEOs arise from chromaffin cells within the adrenal medulla whereas tumors arising from extra-adrenal sympathetic and parasympathetic paraganglia are called PGLs (Pacak et al. 2007, Pacak 2011). The majority of PHEOs/PGLs are benign tumors but metastasis can also occur, especially in patients with a specific genetic background (Brouwers et al. 2006, Ayala-Ramirez et al. 2011, Eisenhofer et al. 2012). In the past, it was postulated that $10 \%$ of these tumors were hereditary, but recent studies show 30-40\% PHEOs/PGLs to be genetically inherited (Neumann et al. 2002, Karasek et al. 2012). Moreover, 10-24\% of apparently sporadic tumors were found to have somatic mutations (Burnichon et al. 2011, Welander et al. 2012, Crona et al. 2014).

In this review, we focus on the role of hypoxia- 
inducible factor signaling in neuroendocrine tumor development.

\section{Update on genetics of PHEO/PGL}

To date, 18 genes predisposing to $\mathrm{PHEO} / \mathrm{PGL}$ development have been identified (Table 1). The susceptibility genes include the $V H L$ tumor suppressor gene, the NF1 tumor suppressor gene, the RET protooncogene, the SDH complex subunits genes (SDHA, $S D H B, S D H C$, and $S D H D)$, and the $S D H A F 2$ gene (Karasek et al. 2012, Vicha et al. 2013). The new PHEO/PGL susceptibility genes include TMEM127, $M A X, H I F 2 A$ and, by anecdotal reports, $K I F 1 B \beta$, PHD2/EGLN1, H-RAS, K-RAS, IDH, FH, and BAPl genes (Hrascan et al. 2008, Ladroue et al. 2008, Schlisio et al. 2008, Gaal et al. 2010, Qin et al. 2010, Astuti et al. 2011, Comino-Mendez et al. 2011, 2013, Jiang and Dahia
2011, Wadt et al. 2012, Zhuang et al. 2012, Crona et al. 2013, Castro-Vega et al. 2014).

Two main clusters, based on the main signaling pathways, currently represent almost all hereditary PHEOs/PGLs: 1) cluster 1, a pseudohypoxic cluster, which is mainly represented by $V H L, S D H x$ and, probably $H I F 2 A$ and $F H$ mutations, and 2) rich in kinase receptor signaling and protein translation pathways, cluster 2 is mainly composed of NF1, RET, $K I F 1 B \beta$, TMEM127, and MAX mutations (Dahia et al. 2005, Gimenez-Roqueplo et al. 2012, Vicha et al. 2013, CastroVega et al. 2014). Although cell signaling in these two clusters seems to be distinct, recent findings uniquely unify important existing connections between signaling pathways in both clusters. Not only that, the HIF signaling pathways appear to be a crucial, perhaps the most important player, in PHEO/PGL tumorigenesis.

Table 1. PHEO/PGL susceptibility genes and genotype-phenotype correlations.

\begin{tabular}{|c|c|c|c|c|c|c|}
\hline $\begin{array}{l}\text { Gene } \\
\text { SDHA }\end{array}$ & $\begin{array}{l}\text { Syndrome } \\
-\end{array}$ & $\begin{array}{l}\text { Locus } \\
5 p 15\end{array}$ & $\begin{array}{l}\text { Inheritance } \\
\text { AD }\end{array}$ & $\begin{array}{l}\text { Biochemical } \\
\text { phenotype } \\
\text { Unknown }\end{array}$ & $\begin{array}{l}\text { Common PHEO/PGL } \\
\text { sites } \\
\text { HNPGL/TAPGL }\end{array}$ & $\begin{array}{l}\text { Malignant } \\
\text { potential } \\
0-14 \%\end{array}$ \\
\hline SDHB & PGL4 & $1 \mathrm{p} 36.13$ & $\mathrm{AD}$ & $\begin{array}{l}\text { MN, NMN, } \\
\text { MTY, NS }\end{array}$ & TAPGL/HNPGL/adrenal & $43 \%$ \\
\hline SDHC & PGL3 & $1 q 21$ & $\mathrm{AD}$ & $\begin{array}{l}\mathrm{MN}, \mathrm{NMN}, \\
\mathrm{NS}\end{array}$ & HNPGL/TAPGL/adrenal & Low \\
\hline SDHD & PGL1 & $11 \mathrm{q} 23$ & AD PI & $\begin{array}{l}\text { MN, NMN, } \\
\text { MTY, NS }\end{array}$ & HNPGL/TAPGL/adrenal & $5 \%$ \\
\hline SDHAF2 & PGL2 & $11 q 13.1$ & AD PI & Unknown & HNPGL & Unknown \\
\hline VHL & VHL & $3 p 25-26$ & $\mathrm{AD}$ & NMN & adrenal/TAPGL/HNPGL & Low $(<5 \%)$ \\
\hline NF1 & NF1 & $17 q 11.2$ & $\mathrm{AD}$ & MN, NMN & Adrenal & $11 \%$ \\
\hline RET & MEN & $10 \mathrm{q} 11.2$ & $\mathrm{AD}$ & MN, NMN & Adrenal & Low $(<1-5 \%)$ \\
\hline MAX & - & $14 q 23.3$ & AD PI & $\begin{array}{l}\text { NMN and } \\
\text { MN }\end{array}$ & Adrenal & $10-25 \%$ \\
\hline TMEM127 & - & $2 q 11.2$ & $\mathrm{AD}$ & $\begin{array}{l}\mathrm{MN} \text { and } \\
\mathrm{NMN}\end{array}$ & Adrenal/TAPGL/HNPGL & Rare $(4 \%)$ \\
\hline HIF2A & $\begin{array}{l}\text { Pacak- } \\
\text { Zhuang }\end{array}$ & $\begin{array}{l}2 \mathrm{p} 21- \\
\text { p16 }\end{array}$ & $\begin{array}{l}\text { Somatic } \\
\text { Germline* }\end{array}$ & $\mathrm{NMN}$ & TAPGL/adrenal & Unknown \\
\hline H-RAS & NA & $11 \mathrm{p} 15.5$ & Somatic & Unknown & Adrenal & Unknown \\
\hline K-RAS & NA & $12 \mathrm{p} 12.1$ & Somatic & Unknown & Adrenal & Unknown \\
\hline IDH1 & NA & $2 \mathrm{q} 33.3$ & Somatic & Unknown & Unknown (HNPGL?) & Unknown \\
\hline KIF1B $\beta$ & NA & $1 \mathrm{p} 36.2$ & Germline & Unknown & Unknown (Adrenal?) & Unknown \\
\hline PHD2/EGLN1 & NA & $1 \mathrm{q} 42.1$ & Germline & Unknown & Unknown (TAPGL?) & Unknown \\
\hline FH & NA & $1 \mathrm{q} 43$ & Germline & Unknown & Adrenal/TAPGL & $\begin{array}{l}\text { Unknown/ } \\
\text { potentially high }\end{array}$ \\
\hline BAP1 & NA & $3 \mathrm{p} 21.1$ & Germline & Unknown & Unknown (TAPGL?) & Unknown \\
\hline
\end{tabular}

*Presenting only with PHEO/PGL together with polycythemia; most likely different from the typical somatic type of HIF2A mutation. $A D$, autosomal dominant; HNPGL, head and neck paraganglioma; $M N$, metanephrine; MTY, metoxytyramine; NMN, normetanephrine; NS, nonsecreting; PGL, paraganglioma; PHEO, pheochromocytoma; PI, paternal inheritance; TAPGL, thoracic or abdominal paraganglioma. 


\section{Hypoxia-inducible factors (HIFs)}

HIFs are transcription factors which are activated under hypoxic or pseudohypoxic conditions and mediate adaptive responses of cells to these states, an idea originally pioneered by Semenza (2011) then later further studied and advanced by others (Schofield and Ratcliffe 2004, Kaelin and Ratcliffe 2008). Hypoxia reflects the lack of sufficient oxygen supply $\left(\mathrm{O}_{2}\right.$ concentration drops below $\left.21 \%\right)$; pseudohypoxia is the state where oxygen is present in a sufficient amount in cells but cannot be processed and further utilized due to an alteration in oxygen-sensing pathways. HIFs are composed of stable, constitutively expressed $\beta$-subunit, and ubiquitously expressed, oxygen-sensitive $\alpha$-subunits, consisting of three isoforms; HIF- $1 \alpha$, HIF-2 $\alpha$, and HIF-3 $\alpha$ (Schofield and Ratcliffe 2004, Kaelin and Ratcliffe 2008, Keith et al. 2012).

Under normoxic conditions, HIF-1 $\alpha$ and HIF-2 $\alpha$ are degraded via the ubiquitin-proteasome pathway, which is controlled by several key enzymatic reactions, the first including prolyl hydroxylation by PHDs (also called as the main $\mathrm{O}_{2}$ sensors) and the second represented by subsequent bindings to the VHL protein (for a review, see Kaelin and Ratcliffe 2008, Koh and Powis 2012). When these enzymatic reactions occur, HIFs do not stabilize well and they are degraded quickly by the proteasome. Additional and less important negative regulation of HIF is mediated via the HIF-3 $\alpha 2$ splice variant (IPAS), which forms inactive complexes with HIF-1 $\alpha$, and also via the FIH1 that hydroxylases HIF on the asparaginyl residue of the C-terminal domain. FIH1 blocks HIF-1 $\alpha$ interaction using coactivators with proteasome ultimately breaking down the complex (Makino et al. 2001, Lando et al. 2002, Jang et al. 2005, Heikkila et al. 2011).

Hypoxia or pseudohypoxia lead to HIF $\alpha$ stabilization and its heterodimerization with HIF- $\beta$, binding of coactivators, and the transactivation of HIF target genes, including those associated with angiogenesis, hematopoiesis, glycolysis, cell growth, and cell migration (Maxwell et al. 2001, Lau et al. 2007, Kaelin and Ratcliffe 2008).

HIF- $1 \alpha$ and HIF- $2 \alpha$ are the best studied isoforms and were found to have mostly complementary, but also opposite functions (Hu et al. 2003, Carroll and Ashcroft 2006, Rankin et al. 2007). HIF-1 $\alpha$ is activated during short periods of severe hypoxia, while HIF- $2 \alpha$ is active under mild hypoxia for more prolonged periods of time
(Holmquist-Mengelbier et al. 2006). Term mild hypoxia is used for oxygen concentrations in tissues of 1-5\% and severe hypoxia is defined as below $1 \%$ (Koh and Powis 2012). The distinct effect of different oxygen concentrations on HIF $\alpha$ activation is mediated by HAF, which marks HIF-1 $\alpha$ for degradation but transactivates HIF- $2 \alpha$ by binding to a different protein site than in HIF-1 $\alpha$ (Koh et al. 2008, 2011). Moreover, both HIF-1 $\alpha$ and HIF-2 $\alpha$ functionally interact with many other signal transduction and transcriptional systems, including NOTCH, WNT, and MYC pathway; thus, HIFs can also regulate gene expression via a hypoxia-independent mechanism (Kaelin and Ratcliffe 2008).

Distinct regulation of HIF $\alpha$ isoforms leads to distinct expression patterns of these transcription factors. HIF- $1 \alpha$ is expressed in all cells, whereas HIF-2 $\alpha$ is preferentially expressed in the endothelium, kidney, heart, lung, gastrointestinal epithelium, and neural crest cell derivatives, including chromaffin cells (Wiesener et al. 2003, Keith et al. 2012). HIF-2 $\alpha$ was shown to play an important role in the regulation of developmental processes of sympathoadrenal lineage; it also regulates catecholamine synthesis and secretion reflected by a typical noradrenergic phenotype (for a review, see Richter et al. 2013).

\section{HIF signaling in tumorigenesis}

HIF interaction with many signaling and transduction pathways and the presence of (pseudo)hypoxia in cancer lead to the presumption that HIF is one of the most important players in tumorigenesis. It was found that both HIF- $1 \alpha$ and HIF- $2 \alpha$ are overexpressed in most human cancers (Zhong et al. 1999, Talks et al. 2000, Hockel and Vaupel 2001). HIF- $1 \alpha$ and HIF- $2 \alpha$ expression in tumors vary among cell types and these differences most probably reflect the consequences of preferential HIF-1 $\alpha$ or HIF-2 $\alpha$ function in different cancer cell subtypes, varying stages of tumor progression (including a degree of hypoxia), and within microenvironmental changes of the tumor (Blouw et al. 2003, Raval et al. 2005, Semenza 2010, Keith et al. 2012). Although both HIF $\alpha$ subunits are often overexpressed in many tumors, HIF- $2 \alpha$ is preferentially linked to more aggressive lesions with a higher metastatic potential or already present metastases (Warnecke et al. 2004, Koh and Powis 2012).

Thus, HIF- $2 \alpha$ overexpression was found to be associated with metastatic progression and poor 
prognosis in specific cancer types, especially astrocytoma, glioma, neuroblastoma, head and neck cancers, and melanoma (Keith et al. 2012). In renal cell carcinoma, in which VHL mutations lead to decreased HIF $\alpha$ degradation by the defective bindings of hydroxylated HIFs to pVHL, HIF- $2 \alpha$ stabilization leads to the tumor formation in mice (Kondo et al. 2003) and protumorigenic genes were shown to be more HIF-2 $\alpha$ dependent (Raval et al. 2005). However, it was also shown that both HIF-2 $\alpha$ upregulation and downregulation can promote tumor development and progression (Kim et al. 2009, Mazumdar et al. 2010) therefore, a certain balance between HIF-1 $\alpha$ and HIF-2 $\alpha$ is needed for optimal function, specifically in tumors. Moreover, HIF- $2 \alpha$ has been shown to regulate HIF- $1 \alpha$ target genes expression in the absence of HIF-1 $\alpha$ and vice versa (Keith et al. 2012, Koh and Powis 2012). Thus, it is not surprising that renal cell carcinomas may be divided into two major subgroups; those preferentially expressing HIF-2 $\alpha$ and those with combined expression of HIF- $1 \alpha$ and HIF-2 $\alpha$.

HIF activation in cancer is mediated not only via the (pseudo)hypoxia signaling pathway but also via multiple oxygen-independent oncogenic pathways, including growth factor signaling pathways and a loss of tumor suppressor genes (for a review, see Jochmanova et al. 2013, Richter et al. 2013).

\section{HIF in PHEO/PGL development}

The role of HIF in the PHEO/PGL pathogenesis has been anticipated for a long time since HIF pathway was previously found to be dysfunctional in these tumors (Maxwell et al. 2001, Dahia et al. 2005, Favier and Gimenez-Roqueplo 2010). Interestingly, most of hereditary PHEOs/PGLs are indeed related to the hypoxia signaling pathway, mainly through the mutations within the VHL, PHD2, FH, SDHx, and SDHAF2 genes (Jafri and Maher 2012, Toledo et al. 2013, Castro-Vega et al. 2014), which lead to increased stability of HIF (GimenezRoqueplo et al. 2001). In the RET- and NF1-associated PHEOs/PGLs, the activation of the RAS-MAPK-mTORC pathway is present, which leads to HIF-1 $\alpha$ activation (Eisenhofer et al. 2004a, Dahia et al. 2005, Johannessen et al. 2005, Foster and Fingar 2010, Lopez-Jimenez et al. 2010). In tumors associated with TMEM127 and MAX mutations, HIF $\alpha$ levels seem to be increased also due to mTORC activation (Brugarolas et al. 2004, Land and Tee 2007; for a review, see Jochmanova et al. 2013). K-RAS and recently described $H-R A S$ mutations in PHEOs/PGLs lead to the activation of the RAS/RAF/ERK pathway, a part of the RAS/MAPK pathway (Hrascan et al. 2008, Crona et al. 2013), and to the increased HIFa signaling. FH mutations result in a loss of fumarate hydratase activity, an enzyme important in the Krebs cycle. $F H$-related PHEOs/PGLs had widespread alterations in protein succination and displayed the same epigenetic changes as SDHB-related tumors (Castro-Vega et al. 2014).

One of the most recently described genes associated with $\mathrm{PHEO} / \mathrm{PGL}$ development is $H I F 2 A$. Initially, somatic gain-of-function $H I F 2 A$ mutations were found in tumors from two female patients with multiple PGLs and polycythemia. One of these patients also presented with somatostatinoma (Zhuang et al. 2012). Subsequently, two other patients with multiple PGLs and somatostatinomas associated with polycythemia were also found to have somatic HIF $2 A$ mutations, suggesting the existence of a new syndrome described by Pacak and Zhuang (Pacak et al. 2013). HIF2A mutations result in HIF-2 $\alpha$ protein stabilization by affecting its hydroxylation, which prevents recognition of HIF-2 $\alpha$ by VHL and results in increased HIF- $2 \alpha$ protein half-life followed by changes in transcriptional activity of many hypoxia-related genes (Zhuang et al. 2012, Yang et al. 2013). Further investigations revealed other patients with PHEO and this syndrome, extending the clinical characteristics of the Pacak-Zhuang syndrome to multiple PHEOs (Taieb et al. 2013). Subsequently, Lorenzo et al. (2013) found a male patient presenting with PHEO and PGLs associated with polycythemia due to a germline HIF2A mutation and Favier et al. (2012) identified a HIF2A mutation in PHEO resected from a 24-year-old female without polycythemia. However, none of these presented with somatostatinoma. Comino-Méndez et al. (2013) described three additional female patients with multiple PHEOs/PGLs and polycythemia and three patients with apparently sporadic disease. The other patient with somatic HIF $2 A$ mutation - female presenting with polycythemia, PHEO, PGLs and somatostatinoma has been described recently by Buffet et al. (2014). They also found a $H I F 2 A$ heterozygous mutation in a male patient with polycythemia and PGL; the mutation was present in the PGL tissue but also as a mosaic in leukocyte DNA and DNA extracted from buccal cells. HIF-2 $\alpha$ stabilization and its involvement in the pathogenesis of PHEOs/PGLs is also supported by the presence of only the noradrenergic biochemical 
phenotype, which reflects the involvement of HIF-2 $\alpha$ in preferential norepinephrine synthesis as described previously (Tian et al. 1998, Eisenhofer et al. 2004b, Nilsson et al. 2005). In summary, the presence of multiple PHEOs/PGLs and duodenal somatostatinomas associated with polycythemia currently seem to only be present in female patients.

Previously, dominantly inherited gain-offunction HIF2A mutations were found to be associated with congenital polycythemia (Percy et al. 2008, Prchal and Gordeuk 2008), which stresses the role of HIF-2 $\alpha$ in the regulation of erythropoiesis. HIF-2 $\alpha$ stabilization and PGL-associated erythropoietin production have been also found in patients with PHD2 and VHL mutations (Ladroue et al. 2008, Capodimonti et al. 2012).

The role of HIF in PHEO/PGL pathogenesis is further supported by the gene expression profiling study, which revealed distinct differences in gene expression between both hereditary and sporadic norepinephrineand epinephrine-producing PHEOs/PGLs including detection of genes involved in hypoxia-angiogenic pathways, especially HIF2A (Eisenhofer et al. 2004b). Later on, in the study of Dahia et al. (2005), cluster 1 tumors were found to display a gene signature of the activated hypoxia pathway, associated with enhanced angiogenesis and extracellular matrix processes, which are known to be HIF-1 $\alpha$ signaling dependent. Subsequent other gene expression profiling studies confirmed strong HIF2A expression in VHL and SDHx tumors (LopezJimenez et al. 2010, Burnichon et al. 2011). Moreover, Lee et al. (2005) proposed that the PHEO/PGL mutations of NF1, RET, VHL and SDHx all act on the same signaling network, resulting in decreased apoptosis (also dependent on the HIF signaling pathway) during chromaffin cell development and tumor formation; additionally, cluster 2 gene mutations seem to enhance HIF- $2 \alpha$ signaling in cells (for a review, see Jochmanova et al. 2013, Richter et al. 2013).

\section{HIF and other neuroendocrine tumors}

The HIF $\alpha$ signaling has also been shown to be upregulated in neuroendocrine tumors other than PHEO/PGL. Some of these tumors are components of hereditary tumor syndromes which can be associated with PHEO/PGL, e.g. VHL disease caused by the mutation of $V H L$ or MEN due to the mutations in the RET protooncogene. In MEN type 1, pituitary, parathyroid and pancreas tumors are present, while in MEN type 2, there are medullary thyroid carcinomas, PHEO, and parathyroid tumors or, simply with mucosal neuromas (Gaztambide et al. 2013, Lodish 2013). Medullary thyroid cancer is rare and typically occurs as a part of MEN2. A recent study by Takacova et al. (2014) brought the experimental evidence for the crosstalk between RET and HIF-1.

Speisky et al. (2012) studied the expression of 52 genes in patients with VHL and sporadic pancreatic neuroendocrine tumors. They found upregulation of genes directly related to HIF signaling ( $C A 9, H I F 2 A$, GLUT1), angiogenesis, epithelial to mesenchymal transition, and metastasis in VHL pancreatic neuroendocrine tumors.

Tumor hypoxia and overexpression of HIF-1 $\alpha$ and HIF-2 $\alpha$ were also found in ileal carcinoids. HIF- $2 \alpha$ expression was significantly higher in distant metastasis compared to a primary tumor in the same patient. Immunohistochemical analysis demonstrated expression of VEGF and CA9. Expression profiling of hypoxic carcinoid cells revealed significant regulation of a large number of genes, including the chemokine receptor CXCR4 (Arvidsson et al. 2010).

It has also been demonstrated that hypoxia can induce NOTCH downstream signaling in several tumor cell lines. Accumulation of HIF- $2 \alpha$ promotes an aggressive phenotype with dedifferentiation and activation of NOTCH signaling in neuroblastoma cells (Jogi et al. 2004, Holmquist-Mengelbier et al. 2006, Sahlgren et al. 2008).

High expression levels of HIF- $1 \alpha$, HIF- $2 \alpha$ and their target genes have been detected in melanoma cells and they were found to be related to a poor prognosis of patients (Zhong et al. 1999, Giatromanolaki et al. 2003, Valencak et al. 2009). Enhanced expression of HIFs, transcription of their target genes, and altered metabolism in melanoma cells during disease progression may promote malignant reprogramming and acquisition of stem cell-like properties and more aggressive and metastatic phenotypes, reviewed by Mimeault and Batra (2013).

\section{Conclusions and future treatment options}

HIF $\alpha$ signaling appears to be a central signaling pathway involved in the pathogenesis of hereditary PHEOs/PGLs, sporadic PHEOs/PGLs, and other neuroendocrine tumors. This designates HIF $\alpha$ as a very promising therapeutic target, especially for more 
aggressive and metastatic tumors where the introduction of HIF- $2 \alpha$ is of the greatest interest at present. Nowadays, several agents affecting HIF-1 $\alpha$ signaling have been introduced, with various results depending on a cancer HIF $\alpha$ phenotype (Liu et al. 2014, for a review, see Melillo 2007a,b). Nevertheless, drugs selectively targeting the HIF-2 $\alpha$ signaling pathways have not yet been described but are currently under development (Rogers et al. 2013, Scheuermann et al. 2013). Moreover, it has been shown that HIF- $1 \alpha$ and HIF-2 $\alpha$ can activate different genes (Keith et al. 2012, for a review, see Koh and Powi 2012); therefore, the development of drugs targeting both HIF- $1 \alpha$ and HIF- $2 \alpha$ is of great interest. It was shown that HAF switches cells from HIF- $1 \alpha$ to HIF$2 \alpha$ signaling; in light of that, one therapeutic approach could be to change the balance of HIF $\alpha$ isoforms by modulating HAF signaling in tumors (Koh et al. 2011). Further investigations are needed to elucidate the other signaling pathways involved in PHEO/PGL development and crosstalk within these pathways and HIF signaling pathway. The combination of two or three drugs, one of them targeting the HIF $\alpha$ signaling pathway and the other two regulating signaling pathways independently of HIFs, could potentially serve as a promising therapeutic strategy in combatting metastatic neuroendocrine tumors, especially PHEO/PGL.

Finding of novel diagnostic tests based on biomarkers (detected either biochemically or by molecular imaging) associated with hypoxia and altered metabolic pathways (by measurement of various metabolites, specifically within the Krebs cycle) should also help to select patients who are likely to respond to that specific type of therapy (e.g. to the HIF signaling inhibitors) and to personalize anti-cancer treatment. We predict that the introduction of novel HIF-related therapies will soon be integrated into medical practices that are specialized in the treatment of neuroendocrine tumors.

\section{Conflict of Interest}

There is no conflict of interest.

\section{Acknowledgements}

Supported by RVO-VFN 64165 and by the Intramural Research Program of the National Institutes of Health, NICHD.

\section{Abbreviations}

BAP1, BRCA1-associated protein-1; CA9, carbonic anhydrase-IX; CXCR4, C-X-C chemokine receptor type 4; ERK, extracellular signal-regulated kinase; $\mathrm{FH}$, fumarate hydratase; FIH1, factor inhibiting HIF; GLUT1, glucose transporter 1; HAF, hypoxia-associated factor; HIF, hypoxia-inducible factor; $H I F 2 A$, hypoxia-inducible factor 2-alpha gene; $H$-RAS, Harvey rat sarcoma viral oncogene; IPAS, inhibitory PAS domain protein; IDH, isocitrate dehydrogenase; KIF1B $\beta$, kinesin family member $1 \mathrm{~B}$, transcript variant $\beta ; K-R A S$, Kirsten rat sarcoma viral oncogene; MAPK, mitogen activated protein kinases; MAX, MYC-associated factor X; MEN, multiple endocrine neoplasia; mTORC, mammalian target of rapamycin complex; MYC, v-myc avian myelocytomatosis viral oncogene homolog; NF1, neurofibromatosis type 1; PGL, paraganglioma; PHD, prolyl hydroxylase; PHD2/EGLN1, prolyl hydroxylase 2; PHEO, pheochromocytoma; pVHL, von Hippel-Lindau protein; RAF, proto-oncogene serine/threonine-protein kinase; RET, rearranged during transfection; $\mathrm{SDH}$, succinate dehydrogenase; SDHAF2, SDH complex assembly factor 2; TMEM127, transmembrane protein 127; VEGF, vascular endothelial growth factor; VHL, von Hippel-Lindau.

\section{References}

ARVIDSSON Y, BERGSTROM A, ARVIDSSON L, KRISTIANSSON E, AHLMAN H, NILSSON O: Hypoxia stimulates CXCR4 signalling in ileal carcinoids. Endocr Relat Cancer 17: 303-316, 2010.

ASTUTI D, RICKETTS CJ, CHOWDHURY R, MCDONOUGH MA, GENTLE D, KIRBY G, SCHLISIO S, KENCHAPPA RS, CARTER BD, KAELIN WG JR, RATCLIFFE PJ, SCHOFIELD CJ, LATIF F, MAHER ER: Mutation analysis of HIF prolyl hydroxylases (PHD/EGLN) in individuals with features of phaeochromocytoma and renal cell carcinoma susceptibility. Endocr Relat Cancer 18: 73-83, 2011.

AYALA-RAMIREZ M, FENG L, JOHNSON MM, EJAZ S, HABRA MA, RICH T, BUSAIDY N, COTE GJ, PERRIER N, PHAN A, PATEL S, WAGUESPACK S, JIMENEZ C: Clinical risk factors for malignancy and overall survival in patients with pheochromocytomas and sympathetic paragangliomas: primary tumor size and primary tumor location as prognostic indicators. J Clin Endocrinol Metab 96: 717-725, 2011. 
BLOUW B, SONG H, TIHAN T, BOSZE J, FERRARA N, GERBER HP, JOHNSON RS, BERGERS G: The hypoxic response of tumors is dependent on their microenvironment. Cancer Cell 4: 133-146, 2003.

BROUWERS FM, EISENHOFER G, TAO JJ, KANT JA, ADAMS KT, LINEHAN WM, PACAK K: High frequency of SDHB germline mutations in patients with malignant catecholamine-producing paragangliomas: implications for genetic testing. J Clin Endocrinol Metab 91: 4505-4509, 2006.

BRUGAROLAS J, LEI K, HURLEY RL, MANNING BD, REILING JH, HAFEN E, WITTERS LA, ELLISEN LW, KAELIN WG JR: Regulation of mTOR function in response to hypoxia by REDD1 and the TSC1/TSC2 tumor suppressor complex. Genes Dev 18: 2893-2904, 2004.

BUFFET A, SMATI S, MANSUY L, MENARA M, LEBRAS M, HEYMANN MF, SIMIAN C, FAVIER J, MURAT A, CARIOU B, GIMENEZ-ROQUEPLO AP: Mosaicism in HIF2A-related polycythemia-paraganglioma syndrome. J Clin Endocrinol Metab 99: E369-E373, 2014.

BURNICHON N, VESCOVO L, AMAR L, LIBE R, DE REYNIES A, VENISSE A, JOUANNO E, LAURENDEAU I, PARFAIT B, BERTHERAT J, PLOUIN PF, JEUNEMAITRE X, FAVIER J, GIMENEZ-ROQUEPLO AP: Integrative genomic analysis reveals somatic mutations in pheochromocytoma and paraganglioma. Hum Mol Genet 20: 3974-3985, 2011.

CAPODIMONTI S, TEOFILI L, MARTINI M, CENCI T, IACHININOTO MG, NUZZOLO ER, BIANCHI M, MURDOLO M, LEONE G, LAROCCA LM: Von Hippel-Lindau disease and erythrocytosis. J Clin Oncol 30: e137-e139, 2012.

CARROLL VA, ASHCROFT M: Role of hypoxia-inducible factor (HIF)-1alpha versus HIF-2alpha in the regulation of HIF target genes in response to hypoxia, insulin-like growth factor-I, or loss of von Hippel-Lindau function: implications for targeting the HIF pathway. Cancer Res 66: 6264-6270, 2006.

CASTRO-VEGA LJ, BUFFET A, DE CUBAS AA, CASCON A, MENARA M, KHALIFA E, AMAR L, AZRIEL S, BOURDEAU I, CHABRE O, CURRAS-FREIXES M, FRANCO-VIDAL V, GUILLAUD-BATAILLE M, SIMIAN C, MORIN A, LETON R, GOMEZ-GRANA A, POLLARD PJ, RUSTIN P, ROBLEDO M, FAVIER J, GIMENEZ-ROQUEPLO AP: Germline mutations in FH confer predisposition to malignant pheochromocytomas and paragangliomas. Hum Mol Genet 23: 2440-2446, 2014.

COMINO-MENDEZ I, GRACIA-AZNAREZ FJ, SCHIAVI F, LANDA I, LEANDRO-GARCIA LJ, LETON R, HONRADO E, RAMOS-MEDINA R, CARONIA D, PITA G, GOMEZ-GRANA A, DE CUBAS AA, INGLADA-PEREZ L, MALISZEWSKA A, TASCHIN E, BOBISSE S, PICA G, LOLI P, HERNANDEZLAVADO R, DIAZ JA, GOMEZ-MORALES M, GONZALEZ-NEIRA A, RONCADOR G, RODRIGUEZANTONA C, BENITEZ J, MANNELLI M, OPOCHER G, ROBLEDO M, CASCON A: Exome sequencing identifies MAX mutations as a cause of hereditary pheochromocytoma. Nat Genet 43: 663-667, 2011.

COMINO-MENDEZ I, DE CUBAS AA, BERNAL C, ALVAREZ-ESCOLA C, SANCHEZ-MALO C, RAMIREZTORTOSA CL, PEDRINACI S, RAPIZZI E, ERCOLINO T, BERNINI G, BACCA A, LETON R, PITA G, ALONSO MR, LEANDRO-GARCIA LJ, GOMEZ-GRANA A, INGLADA-PEREZ L, MANCIKOVA V, RODRIGUEZ-ANTONA C, MANNELLI M, ROBLEDO M, CASCON A: Tumoral EPAS1 (HIF2A) mutations explain sporadic pheochromocytoma and paraganglioma in the absence of erythrocytosis. Hum Mol Genet 22: 2169-2176, 2013.

CRONA J, DELGADO VERDUGO A, MAHARJAN R, STALBERG P, GRANBERG D, HELLMAN P, BJORKLUND P: Somatic mutations in H-RAS in sporadic pheochromocytoma and paraganglioma identified by exome sequencing. J Clin Endocrinol Metab 98: E1266-E1271, 2013.

CRONA J, NORDLING M, MAHARJAN R, GRANBERG D, STALBERG P, HELLMAN P, BJORKLUND P: Integrative genetic characterization and phenotype correlations in pheochromocytoma and paraganglioma tumours. PLoS One 9: e86756, 2014.

DAHIA PL, ROSS KN, WRIGHT ME, HAYASHIDA CY, SANTAGATA S, BARONTINI M, KUNG AL, SANSO G, POWERS JF, TISCHLER AS, HODIN R, HEITRITTER S, MOORE F, DLUHY R, SOSA JA, OCAL IT, BENN DE, MARSH DJ, ROBINSON BG, SCHNEIDER K, GARBER J, ARUM SM, KORBONITS M, GROSSMAN A, PIGNY P, TOLEDO SP, NOSE V, LI C, STILES CD: A HIF1alpha regulatory loop links hypoxia and mitochondrial signals in pheochromocytomas. PLoS Genet 1: 72-80, 2005. 
EISENHOFER G, BORNSTEIN SR, BROUWERS FM, CHEUNG NK, DAHIA PL, DE KRIJGER RR, GIORDANO TJ, GREENE LA, GOLDSTEIN DS, LEHNERT H, MANGER WM, MARIS JM, NEUMANN HP, PACAK K, SHULKIN BL, SMITH DI, TISCHLER AS, YOUNG WF JR: Malignant pheochromocytoma: current status and initiatives for future progress. Endocr Relat Cancer 11: 423-436, 2004a.

EISENHOFER G, HUYNH TT, PACAK K, BROUWERS FM, WALTHER MM, LINEHAN WM, MUNSON PJ, MANNELLI M, GOLDSTEIN DS, ELKAHLOUN AG: Distinct gene expression profiles in norepinephrineand epinephrine-producing hereditary and sporadic pheochromocytomas: activation of hypoxia-driven angiogenic pathways in von Hippel-Lindau syndrome. Endocr Relat Cancer 11: 897-911, 2004b.

EISENHOFER G, LENDERS JW, SIEGERT G, BORNSTEIN SR, FRIBERG P, MILOSEVIC D, MANNELLI M, LINEHAN WM, ADAMS K, TIMMERS HJ, PACAK K: Plasma methoxytyramine: a novel biomarker of metastatic pheochromocytoma and paraganglioma in relation to established risk factors of tumour size, location and SDHB mutation status. Eur J Cancer 48: 1739-1749, 2012.

FAVIER J, BUFFET A, GIMENEZ-ROQUEPLO AP: HIF2A mutations in paraganglioma with polycythemia. $N$ Engl $J$ Med 367: 2161; author reply 2161-2162, 2012.

FAVIER J, GIMENEZ-ROQUEPLO AP: Pheochromocytomas: the (pseudo)-hypoxia hypothesis. Best Pract Res Clin Endocrinol Metab 24: 957-968, 2010.

FOSTER KG, FINGAR DC: Mammalian target of rapamycin (mTOR): conducting the cellular signaling symphony. J Biol Chem 285: 14071-14077, 2010.

GAAL J, BURNICHON N, KORPERSHOEK E, RONCELIN I, BERTHERAT J, PLOUIN PF, DE KRIJGER RR, GIMENEZ-ROQUEPLO AP, DINJENS WN: Isocitrate dehydrogenase mutations are rare in pheochromocytomas and paragangliomas. J Clin Endocrinol Metab 95: 1274-1278, 2010.

GAZTAMBIDE S, VAZQUEZ F, CASTANO L: Diagnosis and treatment of multiple endocrine neoplasia type 1 (MEN1). Minerva Endocrinol 38: 17-28, 2013.

GIATROMANOLAKI A, SIVRIDIS E, KOUSKOUKIS C, GATTER KC, HARRIS AL, KOUKOURAKIS MI: Hypoxia-inducible factors 1alpha and 2alpha are related to vascular endothelial growth factor expression and a poorer prognosis in nodular malignant melanomas of the skin. Melanoma Res 13: 493-501, 2003.

GIMENEZ-ROQUEPLO AP, DAHIA PL, ROBLEDO M: An update on the genetics of paraganglioma, pheochromocytoma, and associated hereditary syndromes. Horm Metab Res 44: 328-333, 2012.

GIMENEZ-ROQUEPLO AP, FAVIER J, RUSTIN P, MOURAD JJ, PLOUIN PF, CORVOL P, ROTIG A, JEUNEMAITRE X: The R22X mutation of the SDHD gene in hereditary paraganglioma abolishes the enzymatic activity of complex II in the mitochondrial respiratory chain and activates the hypoxia pathway. $\mathrm{Am}$ J Hum Genet 69: 1186-1197, 2001.

HEIKKILA M, PASANEN A, KIVIRIKKO KI, MYLLYHARJU J: Roles of the human hypoxia-inducible factor (HIF)-3alpha variants in the hypoxia response. Cell Mol Life Sci 68: 3885-3901, 2011.

HOCKEL M, VAUPEL P: Biological consequences of tumor hypoxia. Semin Oncol 28: 36-41, 2001.

HOLMQUIST-MENGELBIER L, FREDLUND E, LOFSTEDT T, NOGUERA R, NAVARRO S, NILSSON H, PIETRAS A, VALLON-CHRISTERSSON J, BORG A, GRADIN K, POELLINGER L, PAHLMAN S: Recruitment of HIF-1alpha and HIF-2alpha to common target genes is differentially regulated in neuroblastoma: HIF-2alpha promotes an aggressive phenotype. Cancer Cell 10: 413-423, 2006.

HRASCAN R, PECINA-SLAUS N, MARTIC TN, COLIC JF, GALL-TROSELJ K, PAVELIC K, KARAPANDZA N: Analysis of selected genes in neuroendocrine tumours: insulinomas and phaeochromocytomas. J Neuroendocrinol 20: 1015-1022, 2008.

HU CJ, WANG LY, CHODOSH LA, KEITH B, SIMON MC: Differential roles of hypoxia-inducible factor 1alpha (HIF-1alpha) and HIF-2alpha in hypoxic gene regulation. Mol Cell Biol 23: 9361-9374, 2003.

JAFRI M, MAHER ER: The genetics of phaeochromocytoma: using clinical features to guide genetic testing. Eur $J$ Endocrinol 166: 151-158, 2012.

JANG MS, PARK JE, LEE JA, PARK SG, MYUNG PK, LEE DH, PARK BC, CHO S: Binding and regulation of hypoxia-inducible factor-1 by the inhibitory PAS proteins. Biochem Biophys Res Commun 337: 209-215, 2005.

JIANG S, DAHIA PL: Minireview: the busy road to pheochromocytomas and paragangliomas has a new member, TMEM127. Endocrinology 152: 2133-2140, 2011. 
JOGI A, VALLON-CHRISTERSSON J, HOLMQUIST L, AXELSON H, BORG A, PAHLMAN S: Human neuroblastoma cells exposed to hypoxia: induction of genes associated with growth, survival, and aggressive behavior. Exp Cell Res 295: 469-487, 2004.

JOHANNESSEN CM, RECZEK EE, JAMES MF, BREMS H, LEGIUS E, CICHOWSKI K: The NF1 tumor suppressor critically regulates TSC2 and mTOR. Proc Natl Acad Sci USA 102: 8573-8578, 2005.

JOCHMANOVA I, YANG C, ZHUANG Z, PACAK K: Hypoxia-inducible factor signaling in pheochromocytoma: turning the rudder in the right direction. $J$ Natl Cancer Inst 105: 1270-1283, 2013.

KAELIN WG JR, RATCLIFFE PJ: Oxygen sensing by metazoans: the central role of the HIF hydroxylase pathway. Mol Cell 30: 393-402, 2008.

KARASEK D, SHAH U, FRYSAK Z, STRATAKIS CA, PACAK K: An update on the genetics of phaeochromocytoma. J Hum Hypertens 27: 141-147, 2012.

KEITH B, JOHNSON RS, SIMON MC: HIF1alpha and HIF2alpha: sibling rivalry in hypoxic tumour growth and progression. Nat Rev Cancer 12: 9-22, 2012.

KIM WY, PERERA S, ZHOU B, CARRETERO J, YEH JJ, HEATHCOTE SA, JACKSON AL, NIKOLINAKOS P, OSPINA B, NAUMOV G, BRANDSTETTER KA, WEIGMAN VJ, ZAGHLUL S, HAYES DN, PADERA RF, HEYMACH JV, KUNG AL, SHARPLESS NE, KAELIN WG JR, WONG KK: HIF2alpha cooperates with RAS to promote lung tumorigenesis in mice. J Clin Invest 119: 2160-2170, 2009.

KOH MY, DARNAY BG, POWIS G: Hypoxia-associated factor, a novel E3-ubiquitin ligase, binds and ubiquitinates hypoxia-inducible factor 1alpha, leading to its oxygen-independent degradation. Mol Cell Biol 28: 7081-7095, 2008.

KOH MY, LEMOS R JR, LIU X, POWIS G: The hypoxia-associated factor switches cells from HIF-1alpha- to HIF-2alpha-dependent signaling promoting stem cell characteristics, aggressive tumor growth and invasion. Cancer Res 71: 4015-4027, 2011.

KOH MY, POWIS G: Passing the baton: the HIF switch. Trends Biochem Sci 37: 364-372, 2012.

KONDO K, KIM WY, LECHPAMMER M, KAELIN WG JR: Inhibition of HIF2alpha is sufficient to suppress pVHLdefective tumor growth. PLoS Biol 1: E83, 2003.

LADROUE C, CARCENAC R, LEPORRIER M, GAD S, LE HELLO C, GALATEAU-SALLE F, FEUNTEUN J, POUYSSEGUR J, RICHARD S, GARDIE B: PHD2 mutation and congenital erythrocytosis with paraganglioma. N Engl J Med 359: 2685-2692, 2008.

LAND SC, TEE AR: Hypoxia-inducible factor 1alpha is regulated by the mammalian target of rapamycin (mTOR) via an mTOR signaling motif. J Biol Chem 282: 20534-20543, 2007.

LANDO D, PEET DJ, GORMAN JJ, WHELAN DA, WHITELAW ML, BRUICK RK: FIH-1 is an asparaginyl hydroxylase enzyme that regulates the transcriptional activity of hypoxia-inducible factor. Genes Dev 16: 1466-1471, 2002.

LAU KW, TIAN YM, RAVAL RR, RATCLIFFE PJ, PUGH CW: Target gene selectivity of hypoxia-inducible factoralpha in renal cancer cells is conveyed by post-DNA-binding mechanisms. Br J Cancer 96: 1284-1292, 2007.

LEE S, NAKAMURA E, YANG H, WEI W, LINGGI MS, SAJAN MP, FARESE RV, FREEMAN RS, CARTER BD, KAELIN WG JR, SCHLISIO S: Neuronal apoptosis linked to EglN3 prolyl hydroxylase and familial pheochromocytoma genes: developmental culling and cancer. Cancer Cell 8: 155-167, 2005.

LIU XW, CAI TY, ZHU H, CAO J, SU Y, HU YZ, HE QJ, YANG B: Q6, a novel hypoxia-targeted drug, regulates hypoxia-inducible factor signaling via an autophagy-dependent mechanism in hepatocellular carcinoma. Autophagy 10: 111-122, 2014.

LODISH M: Multiple endocrine neoplasia type 2. Front Horm Res 41: 16-29, 2013.

LOPEZ-JIMENEZ E, GOMEZ-LOPEZ G, LEANDRO-GARCIA LJ, MUNOZ I, SCHIAVI F, MONTERO-CONDE C, DE CUBAS AA, RAMIRES R, LANDA I, LESKELA S, MALISZEWSKA A, INGLADA-PEREZ L, DE LA VEGA L, RODRIGUEZ-ANTONA C, LETON R, BERNAL C, DE CAMPOS JM, DIEZ-TASCON C, FRAGA MF, BOULLOSA C, PISANO DG, OPOCHER G, ROBLEDO M, CASCON A: Research resource: Transcriptional profiling reveals different pseudohypoxic signatures in SDHB and VHL-related pheochromocytomas. Mol Endocrinol 24: 2382-2391, 2010. 
LORENZO FR, YANG C, NG TANG FUI M, VANKAYALAPATI H, ZHUANG Z, HUYNH T, GROSSMANN M, PACAK K, PRCHAL JT: A novel EPAS1/HIF2A germline mutation in a congenital polycythemia with paraganglioma. J Mol Med (Berl) 91: 507-512, 2013.

MAKINO Y, CAO R, SVENSSON K, BERTILSSON G, ASMAN M, TANAKA H, CAO Y, BERKENSTAM A, POELLINGER L: Inhibitory PAS domain protein is a negative regulator of hypoxia-inducible gene expression. Nature 414: 550-554, 2001.

MAXWELL PH, PUGH CW, RATCLIFFE PJ: Activation of the HIF pathway in cancer. Curr Opin Genet Dev 11: 293-299, 2001.

MAZUMDAR J, HICKEY MM, PANT DK, DURHAM AC, SWEET-CORDERO A, VACHANI A, JACKS T, CHODOSH LA, KISSIL JL, SIMON MC, KEITH B: HIF-2alpha deletion promotes Kras-driven lung tumor development. Proc Natl Acad Sci USA 107: 14182-14187, 2010.

MELILLO G: Hypoxia-inducible factor 1 inhibitors. Methods Enzymol 435: 385-402, 2007 a.

MELILLO G: Targeting hypoxia cell signaling for cancer therapy. Cancer Metastasis Rev 26: 341-352, $2007 \mathrm{~b}$.

MIMEAULT M, BATRA SK: Hypoxia-inducing factors as master regulators of stemness properties and altered metabolism of cancer- and metastasis-initiating cells. J Cell Mol Med 17: 30-54, 2013.

NEUMANN HPH, BAUSCH B, MCWHINNEY SR, BENDER BU, GIMM O, FRANKE G, SCHIPPER J, KLISCH J, ALTEHOEFER C, ZERRES K, JANUSZEWICZ A, ENG C: Germ-line mutations in nonsyndromic pheochromocytoma. New Engl J Med 346: 1459-1466, 2002.

NILSSON H, JOGI A, BECKMAN S, HARRIS AL, POELLINGER L, PAHLMAN S: HIF-2alpha expression in human fetal paraganglia and neuroblastoma: relation to sympathetic differentiation, glucose deficiency, and hypoxia. Exp Cell Res 303: 447-456, 2005.

PACAK K: Phaeochromocytoma: a catecholamine and oxidative stress disorder. Endocr Regul 45: 65-90, 2011.

PACAK K, EISENHOFER G, AHLMAN H, BORNSTEIN SR, GIMENEZ-ROQUEPLO AP, GROSSMAN AB, KIMURA N, MANNELLI M, MCNICOL AM, TISCHLER AS: Pheochromocytoma: recommendations for clinical practice from the First International Symposium. Nat Clin Pract Endocrinol Metab 3: 92-102, 2007.

PACAK K, JOCHMANOVA I, PRODANOV T, YANG C, MERINO MJ, FOJO T, PRCHAL JT, TISCHLER AS, LECHAN RM, ZHUANG Z: New syndrome of paraganglioma and somatostatinoma associated with polycythemia. J Clin Oncol 31: 1690-1698, 2013.

PERCY MJ, FURLOW PW, LUCAS GS, LI X, LAPPIN TR, MCMULLIN MF, LEE FS: A gain-of-function mutation in the HIF2A gene in familial erythrocytosis. N Engl J Med 358: 162-168, 2008.

PRCHAL JT, GORDEUK VR: The HIF2A gene in familial erythrocytosis. $N$ Engl J Med 358: 1966; author reply 1966-1967, 2008.

QIN Y, YAO L, KING EE, BUDDAVARAPU K, LENCI RE, CHOCRON ES, LECHLEITER JD, SASS M, ARONIN N, SCHIAVI F, BOARETTO F, OPOCHER G, TOLEDO RA, TOLEDO SP, STILES C, AGUIAR RC, DAHIA PL: Germline mutations in TMEM127 confer susceptibility to pheochromocytoma. Nat Genet 42 : 229-233, 2010.

RANKIN EB, BIJU MP, LIU Q, UNGER TL, RHA J, JOHNSON RS, SIMON MC, KEITH B, HAASE VH: Hypoxiainducible factor-2 (HIF-2) regulates hepatic erythropoietin in vivo. J Clin Invest 117: 1068-1077, 2007.

RAVAL RR, LAU KW, TRAN MG, SOWTER HM, MANDRIOTA SJ, LI JL, PUGH CW, MAXWELL PH, HARRIS AL, RATCLIFFE PJ: Contrasting properties of hypoxia-inducible factor 1 (HIF-1) and HIF-2 in von HippelLindau-associated renal cell carcinoma. Mol Cell Biol 25: 5675-5686, 2005.

RICHTER S, QIN N, PACAK K, EISENHOFER G: Role of hypoxia and HIF2alpha in development of the sympathoadrenal cell lineage and chromaffin cell tumors with distinct catecholamine phenotypic features. $A d v$ Pharmacol 68: 285-317, 2013.

ROGERS JL, BAYEH L, SCHEUERMANN TH, LONGGOOD J, KEY J, NAIDOO J, MELITO L, SHOKRI C, FRANTZ DE, BRUICK RK, GARDNER KH, MACMILLAN JB, TAMBAR UK: Development of inhibitors of the PAS-B domain of the HIF-2alpha transcription factor. J Med Chem 56: 1739-1747, 2013.

SAHLGREN C, GUSTAFSSON MV, JIN S, POELLINGER L, LENDAHL U: Notch signaling mediates hypoxiainduced tumor cell migration and invasion. Proc Natl Acad Sci USA 105: 6392-6397, 2008. 
SCHEUERMANN TH, LI Q, MA HW, KEY J, ZHANG L, CHEN R, GARCIA JA, NAIDOO J, LONGGOOD J, FRANTZ DE, TAMBAR UK, GARDNER KH, BRUICK RK: Allosteric inhibition of hypoxia inducible factor-2 with small molecules. Nat Chem Biol 9: 271-279, 2013.

SCHLISIO S, KENCHAPPA RS, VREDEVELD LC, GEORGE RE, STEWART R, GREULICH H, SHAHRIARI K, NGUYEN NV, PIGNY P, DAHIA PL, POMEROY SL, MARIS JM, LOOK AT, MEYERSON M, PEEPER DS, CARTER BD, KAELIN WG JR: The kinesin KIF1Bbeta acts downstream from EgIN3 to induce apoptosis and is a potential 1p36 tumor suppressor. Genes Dev 22: 884-893, 2008.

SCHOFIELD CJ, RATCLIFFE PJ: Oxygen sensing by HIF hydroxylases. Nat Rev Mol Cell Biol 5: 343-354, 2004.

SEMENZA GL: Defining the role of hypoxia-inducible factor 1 in cancer biology and therapeutics. Oncogene 29: 625-634, 2010.

SEMENZA GL: Oxygen sensing, homeostasis, and disease. $N$ Engl $J$ Med 365: 537-547, 2011. Erratum in $N$ Engl $J$ Med 365: 968, 2011.

SPEISKY D, DUCES A, BIECHE I, REBOURS V, HAMMEL P, SAUVANET A, RICHARD S, BEDOSSA P, VIDAUD M, MURAT A, NICCOLI P, SCOAZEC JY, RUSZNIEWSKI P, COUVELARD A: Molecular profiling of pancreatic neuroendocrine tumors in sporadic and Von Hippel-Lindau patients. Clin Cancer Res 18: 2838-2849, 2012.

TAIEB D, YANG C, DELENNE B, ZHUANG Z, BARLIER A, SEBAG F, PACAK K: First report of bilateral pheochromocytoma in the clinical spectrum of $H I F 2 A$-related polycythemia-paraganglioma syndrome. $J$ Clin Endocrinol Metab 98: E908-E913, 2013.

TAKACOVA M, BULLOVA P, SIMKO V, SKVARKOVA L, POTURNAJOVA M, FEKETEOVA L, BABAL P, KIVELA AJ, KUOPIO T, KOPACEK J, PASTOREK J, PARKKILA S, PASTOREKOVA S: Expression pattern of carbonic anhydrase ix in medullary thyroid carcinoma supports a role for RET-mediated activation of the HIF pathway. Am J Pathol 184: 953-965, 2014.

TALKS KL, TURLEY H, GATTER KC, MAXWELL PH, PUGH CW, RATCLIFFE PJ, HARRIS AL: The expression and distribution of the hypoxia-inducible factors HIF-1alpha and HIF-2alpha in normal human tissues, cancers, and tumor-associated macrophages. Am J Pathol 157: 411-421, 2000.

TIAN H, HAMMER RE, MATSUMOTO AM, RUSSELL DW, MCKNIGHT SL: The hypoxia-responsive transcription factor EPAS1 is essential for catecholamine homeostasis and protection against heart failure during embryonic development. Genes Dev 12: 3320-3324, 1998.

TOLEDO RA, QIN Y, SRIKANTAN S, MORALES NP, LI Q, DENG Y, KIM SW, PEREIRA MA, TOLEDO SP, SU $X$, AGUIAR RC, DAHIA PL: In vivo and in vitro oncogenic effects of HIF2A mutations in pheochromocytomas and paragangliomas. Endocr Relat Cancer 20: 349-359, 2013.

VALENCAK J, KITTLER H, SCHMID K, SCHREIBER M, RADERER M, GONZALEZ-INCHAURRAGA M, BIRNER P, PEHAMBERGER H: Prognostic relevance of hypoxia inducible factor-1alpha expression in patients with melanoma. Clin Exp Dermatol 34: e962-e964, 2009.

VICHA A, MUSIL Z, PACAK K: Genetics of pheochromocytoma and paraganglioma syndromes: new advances and future treatment options. Curr Opin Endocrinol Diabetes Obes 20: 186-191, 2013.

WADT K, CHOI J, CHUNG JY, KIILGAARD J, HEEGAARD S, DRZEWIECKI KT, TRENT JM, HEWITT SM, HAYWARD NK, GERDES AM, BROWN KM: A cryptic BAP1 splice mutation in a family with uveal and cutaneous melanoma, and paraganglioma. Pigment Cell Melanoma Res 25: 815-818, 2012.

WARNECKE C, ZABOROWSKA Z, KURRECK J, ERDMANN VA, FREI U, WIESENER M, ECKARDT KU: Differentiating the functional role of hypoxia-inducible factor (HIF)-1alpha and HIF-2alpha (EPAS-1) by the use of RNA interference: erythropoietin is a HIF-2alpha target gene in Hep3B and Kelly cells. FASEB $J$ 18: 1462-1464, 2004.

WELANDER J, LARSSON C, BACKDAHL M, HARENI N, SIVLER T, BRAUCKHOFF M, SODERKVIST P, GIMM O: Integrative genomics reveals frequent somatic NF1 mutations in sporadic pheochromocytomas. Hum Mol Genet 21: 5406-5416, 2012. 
WIESENER MS, JURGENSEN JS, ROSENBERGER C, SCHOLZE CK, HORSTRUP JH, WARNECKE C, MANDRIOTA S, BECHMANN I, FREI UA, PUGH CW, RATCLIFFE PJ, BACHMANN S, MAXWELL PH, ECKARDT KU: Widespread hypoxia-inducible expression of HIF-2alpha in distinct cell populations of different organs. Faseb J 17: 271-273, 2003.

YANG C, SUN MG, MATRO J, HUYNH TT, RAHIMPOUR S, PRCHAL JT, LECHAN R, LONSER R, PACAK K, ZHUANG Z: Novel HIF2A mutations disrupt oxygen sensing, leading to polycythemia, paragangliomas, and somatostatinomas. Blood 121: 2563-2566, 2013.

ZHONG H, DE MARZO AM, LAUGHNER E, LIM M, HILTON DA, ZAGZAG D, BUECHLER P, ISAACS WB, SEMENZA GL, SIMONS JW: Overexpression of hypoxia-inducible factor 1alpha in common human cancers and their metastases. Cancer Res 59: 5830-5835, 1999.

ZHUANG Z, YANG C, LORENZO F, MERINO M, FOJO T, KEBEBEW E, POPOVIC V, STRATAKIS CA, PRCHAL JT, PACAK K: Somatic HIF2A gain-of-function mutations in paraganglioma with polycythemia. N Engl J Med 367: 922-930, 2012. 